\title{
STUDIES
}

Article received on 15 September 2013

Article accepted on 30 September 2013

UDC: $78.01: 141.82$

78.071.1 Вучковић В.

\section{AESTHETICAL VIEWS OF VOJISLAV VUČKOVIĆ IN THE LIGHT OF THEORY OF REFLECTION AND CRITICAL THEORY}

\author{
Milan Milojković* \\ Department of Musicology and Ethnomusicology \\ Academy of Arts in Novi Sad
}

\begin{abstract}
Although Vojislav Vučković (1910-1942) did not leave an elaborate and selfcontained theoretical system behind, his creativity can nevertheless be perceived from a relatively integral perspective, thanks to collections of papers published posthumously. It should be kept in mind that our great composer lost his life at the pinnacle of productivity; hence, we can safely say that his work was interrupted in every sense of the word, and thus left somewhat fragmentary. There is a very significant difference between the views on problem solving he advocated in his early essays and those he promoted before and during the war, given that the timespan involved is just ten years (1932-1942). Based on these 'theoretical wanderings', one could assume that Vučković was following the intensive changes on the West European theoretical stage of his time, endeavouring to shape his standpoints in a dialogue with the main theoretical currents. In this text, I will try to highlight the possible connections between some of Vučković's views and the theories which left an important imprint on the cultural life of Europe between the wars, such as the theory of reflection by Todor Pavlov (1890-1977) and critical (aesthetical) theory by Theodor Adorno (1903-1969) and Walter Benjamin (1892-1940). It should be said that Vučković used Pavlov's theory directly, but in a quite distinctive way which, alongside the theoretical trends of the upcoming generation of Marxist thinkers, was close to the

\footnotetext{
* Author contact information: milanmuz@gmail.com

1 The first draft of this paper was written under the mentorship of Professor Mirjana Veselinović-Hofman within doctoral studies at the Belgrade Faculty of Music in 2013.
} 
critical standpoints of distinguished members of the Frankfurt School, who in those years, like Vučković, were writing new chapters of the history of aesthetics.

Key words: Vojislav Vučković, Theodor Adorno, Walter Benjamin, critical theory, theory of reflection, aesthetics of music

It can be said that Vojislav Vučković (1910-1942) did not leave behind a single comprehensive written work, a magnum opus in the sense of an elaborate and self-contained theoretical system, but his creativity can nevertheless be perceived from a relatively integral perspective, thanks to the collections of papers published after $1945 .^{2}$ Also, our great composer lost his life at the age of 32; hence, we can safely say that his work was interrupted in every sense of the word, and thus left somewhat fragmentary. The differences between the viewpoints advocated in the early essays and those formed before and during the Second World War seem very significant, because the timespan involved is just ten years (1932-1942). Based on these differences, one could assume that Vučković was keenly following the intensive development of the West European theoretical thought of his time, endeavouring to shape his standpoints in a dialogue with the main theoretical currents. In this text, I shall try to highlight possible connections between some of Vučković's views and the theories which left an important imprint on the cultural life of Europe between the wars, such as the theory of reflection by Todor Pavlov (1890-1977) 3 and critical (aesthetical) theory by Theodor Adorno (1903-1969) and Walter Benjamin (1892-1940). It should be said that Vučković used Pavlov's theory directly, but in a quite distinctive way which, alongside the theoretical trends of the upcoming generation of Marxist thinkers, was close to the critical standpoints of distinguished members of the Frankfurt School, ${ }^{4}$ who in those years, like Vučković, were writing new chapters

${ }^{2}$ Famous volumes are Izbor eseja [Selected Essays] (Muzikološki institut, Belgrade, 1955), Umetnost i umetničko delo [Art and a Work of Art] (Nolit, Belgrade, 1962), Vojislav Vučković - Studije, eseji, kritike [Vojislav Vučković - Studies, Essays, Critiques] (Nolit, Belgrade, 1968).

3 The first Soviet edition of Todor Pavlov's theory of reflection was published in 1936.

4 The Frankfurt School is a name referring to a circle of Neo-Marxist theoreticians gathered around the Institute for Social Research [Institut für Sozialforschung] at the University of Frankfurt. Their activities are most often identified as critical theory. They worked intensively in Germany from 1923 to the mid-1930s, and from 1935, the Institute continued its activities in exile, at Columbia University in the USA. After Max Horkheimer's appointment as the head of the Institute in 1930, a strong 'core' was formed, including Theodor Adorno, Erich Fromm, Herbert Marcuse, Friedrich Pollock and others. Although formally not a member of the Frankfurt School, the activities of Walter Benjamin were closely connected to its members, particularly Adorno. 
of the history of aesthetics. The reason why I have chosen to compare the theoretical achievements of our author with Adorno and Benjamin's views is the fact that the methods and theses of these two German thinkers were extremely important for Yugoslav musicology after the War (and consequently, more evident in the papers by our authors, compared to other members of the Frankfurt School), while Vučković's standpoints, related to them, have often been neglected as part of this theoretical context.

Vučković in his texts tackled various fundamental issues of musical aesthetics, almost always being on the line of defining the notion and practice of art (and of a work of art) in dialectic conjunction with the existence of a broader social and historical context and the changes thereof. It can be noted that in the text Muzička umetnost kao subjektivna slika objektivnih stvari [Musical Art as the Subjective Image of Objective Things] the author, pursuing Pavlov's Marxist theory of reflection, defines music 'itself' as a historically conditioned social practice, while in Pregled teorije $i$ istorije estetike [Overview of Theory and History of Aesthetics] he moves from social issues in general to defining the position of music in them; based on that position, he arrives at assumptions about the notion 'itself'. However, as a materialist, Vučković in several places explicitly refused to accept any kind of abstract notion 'in itself', although he nevertheless used some of them in his passionate score-settling with idealism. Today, this 'inconsistency' can hardly be interpreted as an oversight or lack of theoretical skill, bearing in mind that Vučković in his revolutionary zeal undertook to deconstruct and criticize not only traditional aesthetical systems but also Marxist platforms from which he personally approached problems in his texts. Since the environment he originated from and spent his last years in was nowhere near to being able to provide for the development of critical thought at a level comparable to that of the Frankfurters (regardless of their migrations), the 'deviations' and 'distortions' in Vučković's work appear mainly as a consequence of the insufficient preparedness of the language, the culture and social context in Serbia at the time to accept a critical and theoretical potential of such power which later - through the activities of Vučković's contemporaries who, unlike him, lived long enough to formulate their viewpoints in a mature way led to the most significant cultural changes in post-war Europe.

It seems that the Marxist theory of reflection did not leave a significant imprint on our music literature of that time. Before the war, Vučković was one of the few who advocated this standpoint (there was also Pavao Markovac, but he did intervene considerably in the theory), whilst after the war, by 1948, the Soviet literature had been translated, and written works by pre-war authors had 
been published. ${ }^{5}$ In this regard, one could say that Vučković in his early texts described music like an artistic painting, or more specifically, a musical image which is perceived as a musical idea with subjective and objective properties. Vučković defines the objective properties of a musical idea's content as

“...idejni misaoni odraz objektivnih svojstava objekata odraženih u prvobitnoj muzičkoj slici, koja ulaze, dakle, kao već prerađena objektivna svojstva samih objekata, u estetsku muzičku realnost. Tako estetska muzička realnost ne operiše fizički datim objektima, fizički datim muzičkim pojavnim formama kretanja, već njihovom, u svesti apstraktnom i estetski uopštenom muzičkom suštinom, koja postaje osnovni elemenat objektivne strane sadržaja estetske muzičke realnosti i muzičke umetničke slike." 6

In other words, Vučković basically accepts Pavlov's dialectic postulates of the subjective and the objective, whose result is this specific dynamic image. However, right at the moment of this 'acceptance' a language binary barrier is met, since, unlike Pavlov, the "aesthetically generalized musical quintessence" does not owe its objectivity to a partially "natural" connection to what is being reflected; instead, its "material foundation" is in the dynamics of the "adaptation of objective properties," i.e. in constant changes, and changes of the forms of these changes.

This is one of the paradoxes in Vučković's texts. He accepts the theory of reflection, but dismisses its immanent aspiration for the structure of 'scientific Marxism', which would also subject aesthetics to the basic or, in Pavlov's words, "logical and only possible" form of creating the foundations of a "real" science. In contrast to that, Vučković discovers a language barrier in Pavlov's dialectics, precisely while writing about music - which the Bulgarian theoretician cleverly avoided - realizing that a materialist critique (as well as the subject it deals with) must also undergo rapid and radical changes in the quest for new appearances, in keeping with the changes in history and practices. Namely, Pavlov employed his reading of Marx to the benefit of laying the ground for

\footnotetext{
5 That can be seen from the articles available in the regular section "Iz Sovjetskog Saveza" ["From the Soviet Union"] of Muzičke novine [Musical Journal], a periodical published in Zagreb from 1946 to 1948.

6 "...notional abstract reflection of the objective properties of the object reflected in the original musical image, which thus contribute as the already adapted objective properties of the object themselves to the aesthetical musical reality. Therefore, the aesthetical musical reality does not operate with physically given objects, physically given manifestations of musical motion, but with their musical quintessence, abstract and aesthetically generalized, which becomes the basic element of the objective part of the content of the aesthetical musical reality and the artistic musical image." Vojislav Vučković, Umetnost i umetničko delo, Nolit, Belgrade, 1962, 240.
} 
a solid and stable system in the USSR (in the light of the preparations for the upcoming war), while Vučković in his activities was looking for an opportunity to criticize the state of affairs of that day.

On the other hand, Vučković says that

"subjektivna svojstva sadržaja muzičke umetničke slike, ulaze u umetničku sliku, već kao prerađena, objektivizirana, subjektivna muzička svojstva čoveka i tako postaju estetski realna. Samo u objektivnoj realnosti i, preko njenog razvitka, u razvojnom procesu radne i celokupne društvene delatnosti čoveka, subjektivna muzička osećanja i potrebe ljudi mogu nastati, opstati i razvijati se kao ljudska, objektivizirana i društveno realna muzička osećanja i potrebe; samo tako prerađena u umetničkoj slici, ona mogu biti estetski realna." "

By stressing the words "Only in objective reality," Vučković in fact discovers the existence of a subjective reality which, by the logic of things, is not "aesthetically real". However, this also means that "objectification" is the consequence of the "emergence, survival and development" of the objects in the musical image, which leads to the conclusion that the "aesthetical reality" itself is in a dialectical relationship with the non-aesthetical, i.e. "subjective/ non-objectified" reality, and that any aesthetical effect of reality is actually determined by ideology.

Vučković, namely, in many instances explicitly says that aesthetics is a form of ideology, but facing the language of the theory of reflections and the historicist discourse, it is difficult to perceive all the possible meanings of that intervention of his. At this point, it seems that Vučković's notion of ideology was different from Pavlov's, who divided them into the right one and the wrong ones; instead, his critical method succeeded in identifying the operation of ideology even when the right one denied that operation and presented it as a logical scientific fact.

In a lecture titled Teorija napredne muzike [Theory of Progressive Music], Vučković defined music and philosophy precisely as forms of ideology:

"Ponikla pod istim društvenim uslovima - poput filozofije - kao specijalni vid umetnosne istorije društva, muzika u svome razvoju apstraktno oličava onu istu materijalnu supstancu društvenih potreba ljudi, kao i filozofija, razume se, svojim

7 "the subjective properties of the content of the artistic musical image are included in the artistic image as the already adapted, objectified, subjective musical properties of a man, and thus become aesthetically real. Only in the objective reality and, through its development, in the evolutionary process of a man's work and entire social activity, can subjective musical emotions and needs of human beings emerge, survive and develop as human, objectified and socially real musical emotions and needs; only thus adapted in the artistic image can they be aesthetically real." Ibid., 241. 
specifičnim izražajnim sredstvima - pa dakle i iste one osnovne konflikte koji se manifestuju u sukobu između filozofskog idealizma i materijalizma. Zajedničko, prema tome, filozofiji i muzici je to što su i jedna i druga u jednakoj meri ideološki izraz materijalnih odnosa proizvodnje - svaka na svome području i svaka u specifičnom obliku - jednom rečju, dakle, ideologija."

Noting that the existence of music and philosophy is governed by ideology (or that they are "ideological expression"), and that, on the other hand, ideology is the result of production relations, Vučković reduces ideology to its "material" foundations, and seems to be radically denying even Lenin's view about "respect for classical art" in the process, while the discourse of his criticism, at times, can be linked to Adorno's modernist standpoints. Vučković, namely, does not say that music is the same as ideology, but he does not claim the opposite either. However, he finds that, apart from the ideology he writes about, he is also influenced by the ideology he is writing; thus, from the previous argument it follows that music, just like philosophy, as well as the subject and the object cannot be understood "in themselves," but only by means of ideology, image, reflection. Vučković's 'inability' to choose one term speaks of the variability of the parameters that define it and the 'instability' of the language by which it would be defined. The identification of music as an "ideological expression of the material relations of production" mainly confirms the thesis that aesthetics - which deals with "the expression itself," without going into what is "behind" it - is an ideology, or more precisely, that "the expression itself" is in fact (only here, compliance to the theory of reflection is reached) shaped dialectically by the material relations of production and the manner in which ideology determines its perception. This implies that Vučković's subjective image of objective things, unlike Pavlov's, is anti-normative, given that the inventive dialectic game of our author yields the conclusion that the "objective thing" - paradoxically, even as such - is the resultant of ideological mechanisms whose (only) goal is not to mystify repressive bourgeois aesthetics - contrary to what Pavlov says - but which are active for as long as the "objective things" are credited with "objective" properties, derived by "scientific" notional logic. And while Pavlov substantiates his claims with examples from various disciplines and ev-

\footnotetext{
8 "Arising under the same social circumstances - like philosophy - as a special form of the art history of society, music in its development personifies abstractly the same material substance of people's social needs as philosophy does, of course, with its specific means of expression - hence, the same basic conflicts manifested in the collision between philosophical idealism and materialism. Therefore, the common ground between philosophy and music is that both of them, to an equal extent, are ideological expressions of the material relations of production - each in its domain and each in a specific form - hence, in a word, an ideology." Ibid., 98.
} 
eryday life, in order to prove the universality of his theory, Vučković remains in the domain of art, particularly music, striving to put the exact aesthetic discourse that is the origin of his views 'on a sound footing'. His seven years older contemporary, Theodor Adorno, will begin his famous treatise Aesthetic Theory from a similar position, stressing that "it is self-evident that nothing concerning art is self-evident anymore, not its inner life, not its relation to the world, not even its right to exist". ${ }^{9}$

It is important to emphasize that even Adorno, in the exact same confrontation of basic philosophical premises with the theory and practice of music, almost at the same time as Vučković, reached similar theoretical postulates, which later, naturally, he elaborated in detail. The aesthetics (of music), constituted as a necessary ideological mediator between a work and the audience, is the thesis that brings Vučković and Adorno closer together. Also, one can say that Adorno's texts about music and aesthetics are in fact his critique of the context he originated from. Moreover, Lucia Sziborsky thoroughly argues the premise that Adorno critiqued the discourses of philosophy and sociology (the disciplines in which he became a cornerstone personality of the $20^{\text {th }}$ century) and enriched them with new achievements, approaching them exactly from his 'parent' aesthetical and musical context. ${ }^{10}$

Adorno and Vučković are also brought closer together by the view that the musical matter 'itself' - which in fact can only be established in a theory, i.e. aesthetics - cannot reflect anything but its own "objective aesthetical reality," which is, on the other hand, determined by history and ideology. This implies that music endeavouring to express (something beyond itself) enters the domain of ideology, while the aspiration to establish a relationship between the "specifically musical" and the social circumstances, and to find a form of musical expression suitable for the current historical moment, remains the area of constructive criticism and opposition to repressive ideological mechanisms. ${ }^{11}$

It can be understood that Vučković's discourse (perhaps it would not be inappropriate to use the plural - Vučković's discourses - since a universal profile

9 Teodor Adorno, "Estetička teorija" [Theodor Adorno, "Ästhetische Theorie"], in: Marksizam i umjetnost [Marxism and Art] (ed. Vjekoslav Mikecin), Komunist, Belgrade, 1976, 126.

${ }^{10}$ Lusija Sciborski, "Dijalektika iz duha muzike" [Lucia Sziborsky, "Dialektik aus dem Geist der Musik"], in: Treći program [The Third Programme], No. 73, Belgrade, 1987, 258289.

11 Put simply, Adorno maintained that Schönberg had reached the socially 'suitable' form of a work in his atonal phase, unlike Stravinsky, who, in his opinion, demanded that social norms be accepted as reality. For more details cf. Teodor Adorno, Filozofija nove muzike [Theodor Adorno, Philosophie der neuen Musik], trans. Ivan Focht, Nolit, Belgrade, 1968. 
of his texts is certainly impossible to create) is a token of the theoretical current which was spreading from the Soviet Union across Europe in the 1930s. His interpretation of Pavlov is substantially different from similar interpretations that appeared in the dogmatic environment of the USSR, ${ }^{12}$ since Vučković's position was exceptional compared to his environment. Thus, even when he writes in a language close to socialist realism, he implies a demand for change, for revolution. In the USSR, on the contrary, socialist realism meant that this exact demand was fulfilled.

In the second part of the text Teorija napredne muzike, under the subtitle Materijalizam [Materialism], Vučković clearly defines his view about the relationships between music and society, identifying it as the consequence of a conjunction between aesthetics and the social context that changes through history.

"Svako razdoblje imalo je svoje shvatanje muzike, iz koga je proizlazila odgovarajuća interpretacija odnosa između muzike i čoveka, odnosno društva."

In other words, it seems that the interpretation of Vučković's standpoints can also be formulated as the perception of how much the structure of music is burdened with the 'sediments' of historical meaning, which is regulated by ideology. However, this dialectical relationship also implies that music follows social changes, but always in its 'autonomous' way, being ideologically mediated. In this way, Vučković once more dismisses the idea that things are reflected immediately in any kind of art, contrary to Pavlov's claim that a natural, objective reality in art must exist, and that it is fathomable only by studies based on "scientific Marxism". Putting music and society in a dialectical relation - not only with one another, but between them as the object (music and society) with the subject approaching them (Vučković) - is certainly closer to Adorno's view about the "autonomy of art" than to Pavlov's theory of reflection.

Another agreement with Adorno is when Vučković vindicates Hába's convictions about the necessity to overcome musical means historically. Namely, he advocates Hába's view that a triad is not a natural sonority, a stipulation for the aesthetic, but that its perception is conditioned by history. ${ }^{14}$ However,

${ }_{12}$ Cf. articles available in Muzičke novine, in the regular section "Iz Sovjetskog Saveza". The journal was published in Zagreb, from 1946 to 1948.

13 "Every period had its own comprehension of music, which has yielded an appropriate interpretation of the relationships between music and man, i.e. society." Vojislav Vučković, Umetnost..., 106.

14 "Svaki trozvuk što ga danas neki skladatelj još uporabi zvuči kao negacija u međuvremenu oslobođenih disonanci. On više nema neposrednosti koju je nekad imao i koja se potvrđuje njegovom današnjom, nego je nešto povijesno posredovano" ["Every triad, still used by 
Vučković does not share Adorno's support for Schönberg, but he does give him credit for noting the social determination of musical production, exactly through its radical negation and operation in the domain of 'pure music'. He reproached Schönberg for the use of "old systems," referring to traditional procedures in his works and perceiving the paradox of their application in contemporary music, which Adorno agrees with on principle. ${ }^{15}$

Another link between Vučković and the dominant Marxist currents of the 1930s is the introduction of the notion of fetishism. It does not become as fundamental as with Walter Benjamin, ${ }^{16}$ but for exactly this reason, it is important to compare the directions of this term's evolution and its functionality in the theoretical activities of the two authors. As Vučković says:

"Ta fetišizacija odnosa među ljudima - izdvajanje pojava iz njihovog razvojnog toka, to nasilno raskidanje njihove uslovljenosti - oličava i onu, danas veoma rasprostranjenu ideologiju muzičke umetnosti, čije su materijalne osnovice iste kao kod filozofskog idealizma, ideologiju koja izvan izražajnih sredstava muzike ne vidi nikakvu svrhu umetnosti, pa ta sredstva proglašava sama sebi svrhom, tu muzičku ideologiju, čije je idejno uporište Kantov idealizam, a društvena pozadina, borba protiv progresa i nauke, protiv prirode razvitka (podvukao M. M.); ta muzička ideologija, koja svoja izražajna sredstva negira kao sredstva i nasilno ih proglašava ciljem, inkarnirana je u pojmu apsolutna muzika. Apsolutna muzika je umetnosni vid filozofskog idealizma, ona je inkarnacija muzičkog idealizma." ${ }^{\prime 17}$

some composers today, sounds like a denial of dissonances liberated in the meantime. It no longer has the directness it used to have, which is confirmed by its directness today; instead, it is something mediated by history"]. Teodor Adorno, "Teškoće u skladanju i u shvaćanju nove glazbe" [Theodor Adorno, "Schwierigkeiten beim Komponieren Neuer Musik"], in: Nova filozofija umjetnosti (ed. Danilo Pejović), Nakladni zavod Matice Hrvatske, Zagreb, 1972, 136-137.

15 Adorno in fact emphasizes that the "statička dvanaesttonska tehnika ostvaruje osjetljivost muzičke dinamike prema nemoćnom vraćanju istoga" ["static twelve-tone technique actualizes the sensitivity of musical dynamics in the face of the unconscious recurrence of the same"]. Teodor Adorno, Filozofija nove muzike, Nolit, Belgrade, 1968, 89.

16 Apart from a similarity with the title of Benjamin's famous text Das Kunstwerk im Zeitalter seiner technischen Reproduzierbarkeit [The Work of Art in the Age of Mechanical Reproduction], Vučković's chapter titled Problem reproduktivnih umetnosti [The Issue of the Performing Arts] (in: Vojislav Vučković, Umetnost..., 214) also bears other resemblances to the theoretical work of this German philosopher, although on a much more modest scale.

17 "This fetishism of relations between humans - uprooting phenomena from their evolutionary course, this violent severing of their interdependence - depicts the ideology of musical art, remarkably widespread today, whose material foundations are the same as those of philosophical idealism; the ideology which does not see any purpose of art beyond the expressive means of music, and so proclaims that these means are an end in itself; this musical ideology, grounded in Kant's idealism and socially oriented towards the battle against prog- 
And a little later, he adds:

"Nerazlikovanje umetnosti od umetničkog dela (izražajnog materijala umetnosti) prouzrokovalo je fetišizam umetnosti, koji je onemogućio pravo naučno razrešenje problema umetnosti i razvoj estetike kao nauke, jer je na tim temeljima zasnovanoj nauci o umetnosti osujetio:

1. određivanje objektivnog kriterijuma vrednosti u umetnosti

2. naučnu teoriju razvoja umetnosti

3. neophodnu distinkciju između nauke i umetnosti." 18

Although it seems that Vučković in the quoted excerpt returns to the fold of the theory of reflection, significant deviations from Pavlov's orientation are apparent. First, it should be borne in mind that Vučković's notion of the nature of evolution is undoubtedly linked to Pavlov's construct about social progress. However, when Pavlov in Stalin's USSR speaks of "the nature of evolution" as a necessity immanent to progress, it is clearly a paradox, a language barrier, since "progress" or "evolution" in Pavlov's text is certainly "natural" and thus necessary, and so its "nature" is exactly what "natural evolution" turns it into which is a repercussion of the totalitarian ambition to present the current state of society as the ultimate so far and as a "natural" consequence of "evolution," whose "nature" is, after all "natural" and thus only possible/logical/permitted, etc. Ipso facto, the art created under the ideological influence of capitalist production results in the fetishism of artefacts and relations established in that context no more and no less than the art created in the Soviet environment of the USSR, since the relationship between art and society in both cases is to be presented as directly conditioned, and the form of that conditioning as the only one possible.

Naturally, in Vučković's case such demagogical twists were out of place, since he worked in the Kingdom of Yugoslavia, whose social system was dia-

ress and science, against the nature of evolution (italicized by M. M.); this musical ideology which denies its own expressive means as such and forcibly declares them to be the goal, is incarnated in the notion of absolute music. Absolute music is the artistic counterpart of philosophical idealism; it is the incarnation of musical idealism." Vojislav Vučković, Umetnost..., 100.

18 "Not distinguishing art from a work of art (the expressive means of art) gave rise to the fetishism of art, which impeded a true scientific solution to the problem of art and development of aesthetics as science, because it made it impossible for such a founded science of art to:

1. determine the objective criteria of value in art

2. develop a scientific theory of evolution of art

3. make the necessary distinction between science and art." Ibid., 103-104. 
metrically opposite to that of the USSR. In this regard, the nature of evolution in Vučković's work can be understood as an unattainable ideal, something that is perceptible in theory, but has never happened in "objective reality" because of the ubiquitous operation of ideology, "shaped by the relations of production". However, as already noted, Vučković does not proclaim, unlike Pavlov, but expresses his efforts and the goals he aims for. Therefore, when he demands "the objective criteria of value" or the "scientific theory of evolution," he does not give a theoretical justification for the already current practice, i.e. legitimization of a fetish relationship; instead, he uses these distinctive theoretical 'slogans' to criticize the current state of affairs.

The origin of these 'slogans' or 'phrases' can be found in the theory of reflection, analogously to the syntagm the nature of evolution - objectivity and value are in fact the criteria, the only possible theory of evolution is the one evolution has led to, and since science is another product of that evolution, that theory is certainly scientific. However, precisely for this reason, these 'phrases' in Vučković's work are a criticism of capitalist exploitation in Yugoslavia (and generally, in the West at the time), while Pavlov used them to present the Soviet type of production as the prerequisite for their existence "in reality". This once more emphasizes Vučković's connection with critical theory: unlike the Marxists from the USSR, he does not accept that the economic base is even possible as 'objective', since ideology is its reflection as much as it influences its functioning. In other words, the Soviets maintained that the change of society's economic base will also lead states to the desired ideological positions through a direct conjunction, ${ }^{19}$ and thus, for example, art created in a socialist economy will reflect socialist ideals. However, since Vučković was in opposition to the society and state(s) which he lived and worked in, his standpoint was that this fetishism of the relationship between the base and the superstructure could turn around through criticism, realizing that such consequent reciprocity, whose implementation was strived for in the USSR, cannot be carried out precisely because - as Pavlov, Adorno and Vučković all observe, each in their own way - ideology does indeed 'reflect' material circumstances, but instead of doing it directly and immediately, it operates exactly in its own autonomous domain which can take various forms, such as philosophy or music, to name the examples that Vučković uses. At the same time, this is a view that was developed by the Western Marxist school of thought, particularly after the war, in the domain where the critique of both Soviet practice and its parent neoliberal context was possible.

19 Aleksandar Vacić, "Robna privreda u Sovjetskom Savezu" ["Commodity Production in the Soviet Union"], Treći program [The Third Programme], No. 4, Belgrade, 1971, 37-178. 
Thus, Vučković demands "objective criteria" in art, having in mind that the previous aesthetic parameters were influenced by "philosophical idealism," which is a reflection of the economic system of his time. These "objective criteria," in Vučković's opinion, must be established within a scientific discipline which would regard aesthetics as a discourse-object. Thus, it can be assumed that although art must be differentiated from science, it is the scientific domain which determines the "objective criteria of value" that define art. In this case, science is understood as a realm of social practice where a broad consensus exists as to what the object approached scientifically is. Naturally, Vučković demands that such science must be founded on the principles of dialectic materialism, in order to create not only a necessary distance from the work of art, but also a connection to current and broader social developments. Such a vision of the relationship between science and art seems to correspond to certain principles from Benjamin's text Der Autor als Produzent [The Author as Producer], ${ }^{20}$ which refer exactly to the Soviet practice of socialist realism of that time.

There is another point where Vučković's dialectic method of analysis clashes with the theory of reflection, when he defines the programmatic dimension in music thus:

"Drugi, iako po metodi, postupku i sadržini stvaranja istovetni sa prvima, samu tu igru izražajnog materijala negiraju kao samostalnu i besciljnu igru i nastoje da je prikažu kao nosioca izvesne striktne idejne sadržine, koja je imanentna toj igri već po tome što je tvorca inspirisala nezavisno od sadržajne neodređenosti, idejne nekonkretnosti njenog delovanja na ljude."21

The 'inconsistency' apparent in Vučković's interpretation of Pavlov allows us to ascribe this radical view to his theoretical 'looking ahead'. In fact, this standpoint challenges the aesthetic right to the practice of socialist realism of

20 Both in Benjamin's and Vučković's work, the criticism of the bourgeois "total autonomy" of scientific and art disciplines is highly conspicuous: "In unserem Schrifttum, sind Gegensätze, die sich in glücklicheren Epochen wechselseitig befruchteten, zu unlösbaren Antinomien geworden. So fallen Wissenschaft und Belletristik, Kritik und Produktion, Bildung und Politik beziehungslos und ungeordnet auseinander." ["In our literature, oppositions which mutually enriched each other in earlier, happier times, have become insoluble antinomies. Thus, science and belles lettres, criticism and production, culture and politics have fallen away from each other, without maintaining any relationship or order."] Cf. Valter Benjamin, Eseji [Walter Benjamin, Essays], Nolit, Belgrade, 1974, 100.

21 "The latter, although the same as the former in method, procedure and content of creation, deny this very play of expressive material as a self-contained and goalless game and strive to present it as a proponent of a certain strict idea of content, which is immanent to that game already by its having inspired the creator, regardless of its content being indeterminate and its effect on people being nonspecific." Vojislav Vučković, Umetnost..., 101. 
the 1930s, which in the search for the 'primordial' social determination of art promoted a conventional and, at that time, already obsolete manner of artistic production. The 'organic functionality' of socialism resided in political power, i.e. the needs of the government during that period, which was just the opposite of what Vučković was advocating at that moment. In his critical perception of history, he actually offers ideological determinants for all the important currents of the musical production of his time and, judging by the following remarks, he does not see them as progressive:

"Klasičari, odriču potrebu traženja vanmuzičke svrhe u umetnosti, proglašavaju izražajna sredstva muzike apstraktno i bez veze sa njihovim efektom kao isključivu sadržinu muzičke umetnosti.

Bečki konstruktivisti, koji izričito negiraju svaku vanmuzičku svrhu umetnosti priznaju eo ipso istu formulaciju.

Neoromantičari, za koje su izražajna sredstva muzike nosioci striktne društvene sadržine izričito ozakonjuju njihovu identifikaciju.

Neoklasičari, koji odriču sadržajno (u vanmuzičkom smislu) delovanje muzike, proglašavaju muzičku formu, tj. muzička izražajna sredstva jedinom sadržinom muzičke umetnosti." 22

Thus, it can be said that art as an expression of class warfare remains Vučković general orientation, comprising that which is reflected, that which reflects and the reflection itself in a complex dialectic interdependence.

The artist and fighter, as they called him, Vojislav Vučković apparently waged a significant battle to shape his theoretical views in the tumultuous interwar years, challenging his own ideas no less than domestic music writers who, later on, struggled aiming to present and experience them as a symbol of the effort of progressive Yugoslav thinkers to carry out a revolution. ${ }^{23}$ As Mirjana Veselinović-Hofman says, "upravo je u tim [...] gradirajućim i veoma drago-

22 "Classicists deny the need to look for extramusical purpose in music, proclaim that the expressive means of music are the exclusive content of musical art, abstractly and with no relation to their effect.

Viennese Constructivists, who expressly deny any extramusical purpose of art, concede eo ipso the same formulation.

Neoromanticists, for whom the expressive means of music are proponents of strict social content, expressly legitimize their identification.

Neoclassicists, who deny that music operates through an extramusical content, proclaim that the musical form, i.e. expressive means of music, is the only content of musical art." Ibid., 103.

${ }^{23}$ Interesting observations about this in: Nikola Hercigonja, "Aktuelnost Vučkovićeve misli" ["Topicality of Vučković's thought"], Treći program [The Third Programme], No. 28, Belgrade, 1976, 359-382. 
cenim 'iskliznućima' iz svoje ideološke 'disciplinovanosti', Vučković ispoljio znatnu fleksibilnost pri obradi svojih polaznih, krajnje odsečno izrečenih teorijskih pretpostavki". ${ }^{24}$ Although fragmentary, Vučković's work is a rare historic document about the influence of West European non-dogmatic Marxist thought in the 1930s on the domestic theoretical output, particularly the musical one. The aim of this paper was not to show that Vučković's work had the same significance as the Frankfurt School, nor that it foreshadowed the arrival of socialist realism, but that this author's texts, like similar ones in the Czech Republic, Hungary, Germany, or in France, are an example of the distinctive theoretical currents in the interwar Europe. Also, such a 'historical' reading of Vučković allows us to gain an insight into the dogmatism of domestic theoretical production after the war and to follow the gradual and controlled 'release' from these chains. On the other hand, from today's standpoint, Vojislav Vučković, apparently riding a powerful revolutionary wave which hinted at the subsequent dramatic events, developed his Marxist thought through a critique of the existing state of affairs, even a critique of his own views, conforming his activities largely to the topical interventions in the aesthetical theory, which was at the time shaken by radical blows both from the East and the West.

\section{Summary}

U susretu sa teorijom odraza Todora Pavlova, Vojislav Vučković je u svojim tekstovima postavio brojna značajna pitanja o vezama između muzike i društva, kao i o estetici koja njihov odnos definiše. Međutim, postavke bugarskog teoretičara u delu našeg autora doživljavaju značajne izmene, približavajući ga teorijskim strujama zapadnoevropske marksističke misli. Fokusirajući se na odnos između umetničkog dela i društvenih praksi, Vučković je problematizovao direktnu uslovljenost umetnosti, kao nadgradnje, ekonomskom bazom, postavljajući pitanja o "objektivnosti" estetike i principa "naučnog" marksizma. Za razliku od Pavlova, Vučković je estetici prišao kritički, te nije prihvatio njenu jednostranu posredničku ulogu u odnosu između muzike i društva, već je odredio kao vid ideologije kojim se utiče na formiranje "subjektivnih slika objektivnih stvari". Samim tim, "objektivna stvar" za Vučkovića nije moguća van delovanja estetike, dakle ideologije, čime je uveo u raspravu i pitanja o autonomiji umetnosti, koju je video kao područje klasne borbe. Skrećući sa Pavlovljeve linije, Vučković nije ideologiju dogmatski posmatrao kao ispravnu i pogrešne, već je nastojao da ideološko delovanje uoči i kritički sagleda

24 "it is precisely in these [...] gradual and very valuable 'deviations' from his being ideologically 'disciplined' where Vučković manifested considerable flexibility in processing his initial, very brusquely stated theoretical premises." Mirjana Veselinović-Hofman, Pred muzičkim delom [Facing a Musical Work], Zavod za udžbenike, Belgrade, 2007, 255. 
bez obzira da li ono dolazilo od tradicionalnih represivnih mehanizama ili iz pravca marksističke teorije kojoj je sam pripadao. Takav pristup odnosu između umetnosti i društva je našeg autora približio stavovima kritičke teorije Teodora Adorna i Valtera Benjamina, koji su upravo u tom periodu snažno kritikovali kako tradicionalne estetičke sisteme tako i savremena nastojanja bez obzira da li su ona dolazila sa istoka ili sa zapada Evrope.

Translated by Goran Kapetanović 